\title{
MONITORING CHLOROPHORUS VARIUS MULL IN MANGO ORCHARDS IN EGYPT
}

\author{
HASHIM, SALAH M. \\ Plant Protection Research Institute, ARC, Dokki, Giza, Egypt.
}

(Manuscript received 10 March 2013)

\begin{abstract}
Population fluctuation of Chlorophorus varius (Coleoptera: Cerambycidae), attacking mango trees was monitored at Ismailia governorate during the two successive years of 2010 and 2011.

C. varius prevailed from early / late April to early November. Summer recorded the maximum flight $(1.16-1.36$ beetles), followed by spring ( $0.51-0.70$ beetle), then autumn $(0.15-0.18$ beetle)/tree, and stopped during winter. The total numbers per year were $1.82-2.24$ beetles / tree. It had two brood and the beetles' activity averaged $7-7.5$ months.

Effect of weather factors on the borers' activity was mostly positively significant with daily maximum, daily minimum and daily mean temperatures but negatively and insignificantly with daily mean relative humidity. Infestation was almost doubled during only one year, thus urgently need to apply integrated approaches for control.
\end{abstract}

\section{INTRODUCTION}

Field observations allover the governorates of Egypt (Hashim 2009) indicated that the major stem boring insect pests in mango (Mangifera indica) orchards at both old valley lands and new reclaimed desert lands were the following Coleopterous species: Chlorophorus varius, Macrotoma palmata, Pseudocastalia aegyptiaca, Batocera rufomaculata, Stromatium vulvum, Ptosima undecimmaculata, Belionota scutellaris, Chrysobothris dorsata, Anthaxia angustipennis, Niphona picticornis, Scolytus amygdali, Xylotrechus antilope, Hypothenemus eruditus, Xyleborus similis, Xyleborinus saxeseni, Mesites cunipes, Rhyncolus cylindricus, Lyctus africanus, Gastrallus striatus, Tropiderinus munieri, Bostrychopsis reichei, Dinoderus bifoveolatus, D. minutus, Enneadesmus obtusedentatus, E. trispinosa, E. forficula, Phonapate frontalis, Sinoxylon sudanicum.

Successful integrated pest control depends largely on monitoring studies especially the sesonal fluctuation in the target pest population, the progress of infestation, the seasonal cycle, and the effect of the main weather factors on the target pest. However, the literature in this respect is lacking allover the world and there were some scattered researches in Egypt (Kinawy et al., 1993, Tadros, 1994, Tadros et al., 2006 and Hashim, 2009).

Abdel-Hamid (2005), studied the seasonal abundance, progress of infestation and effect of weather factors on C.varius beetles during 2010 and 2011 seasons in 
peach, apricot, plum and almond orchards.

In an attempt to contribute to such a gap in the knowledge, the present study is carried out to add new information that may help in planning of rather effective "Integrated Control Programs" for the management of tree borers in mango orchards.

\section{MATERIALS AND METHODS}

\section{Population fluctuation of apricot tree boring insect pests:}

\subsection{Seasonal abundance:}

Mango orchard (about 5 feddans with trees approximately more than 20 years old) located at El-Tall Kabeer, east Delta, Ismailia governorate were subjected to monitoring studies of the target boring insect. Monitoring studies were carried out during two successive years extending from early January, 2010 until late December, 2011. No chemical treatments were applied in the selected areas throughout population fluctuation studies. A paint marker using a brush canceled the old exit holes on 100 infested trees with $C$. varius randomly distributed in the orchard.

From January $1^{\text {st }}, 2010$ until December 31, 2011, the new exit holes - indicating emergence of beetles of $C$. varius borer's species were counted at half-monthly intervals on the $15^{\text {th }}$ and last day of every month. To avoid repeated counting new exit holes were immediately canceled with a spray / pin paint marker after counting.

\subsection{Progress of infestation:}

Data of the seasonal abundance were accumulated from January $1^{\text {st }}, 2010$ until December 31, 2011 for each half-monthly interval. The total number of beetles represented the accumulated number for the two years together. To smooth the frequency distribution curve, data were analyzed according to the following formula:

$\{(2 \times$ the actual number $)+$ the previous number + the following number $\} / 4$

The presented figures indicated the periods of the seasonal cycles of beetles activity and inactivity. Progress of infestation also indicated the rate of increase in the borer infestation year after another.

\section{Effect of weather factors on the activity of apricot tree borers:}

Four main weather factors, the day maximum temperature (DMxT), day minimum temperature (DMnT), day mean temperature (DMT) and day mean relative humidity (DMRH) were considered. Necessary weather data were obtained from the Central Laboratory of Climate and Meteorology, ARC, MOA, Giza.

Population data of $C$. varius and the meteorological data, both at half-monthly intervals, were presented.

The relationship between the four weather factors and the target borer during the activity season was investigated for two successive years extending from January 2010 until December 2011 in the mango orchard.

To determine the direct effect of each weather factor on $C$. varius activity, 
population counts were plotted against the corresponding weather data. The simple correlation coefficients " $r$ " for the relationship between each weather factor and each insect species population was then worked out (Snedecor and Cochran, 1990).

\section{RESULTS AND DISCUSSION}

\section{Population Fluctuation of Chlorophorus varius:}

\subsection{Seasonal abundance:}

Table (1) and Figure (1) showed that beetle's emergence prevailed during the period from the $1^{\text {st }} / 2^{\text {nd }}$ half of April to $1^{\text {st }}$ half of November in mango orchards during 2010 and 2011.

Beetles started to emerge during the $1^{\text {st }}$ half of April ( 0.01 beetle / tree) in 2011 and the $2^{\text {nd }}$ half of April ( 0.02 beetle / tree) in 2010. Three flight peaks were recorded in 2010 and 2011. The first peak was observed during $2^{\text {nd }}$ half of May 2011 ( 0.18 beetle / tree) and during the $1^{\text {st }}$ half of June 2010 ( 0.19 beetles / tree). The second peak was noticed during $2^{\text {nd }}$ half of June 2011 ( 0.29 beetle / tree) and during the $1^{\text {st }}$ half of July 2010 ( 0.24 beetles / tree). The third peak was noticed during $2^{\text {nd }}$ half of August 2010 ( 0.32 beetle / tree) and during the $1^{\text {st }}$ half of September 2011 ( 0.36 beetles / tree). Emergence of beetles was ceased during the $1^{\text {st }}$ half of November 2010 ( 0.01 beetle / tree), and 2011 (0.02 beetle / tree).

The maximum beetles' flight ( 1.16 and 1.36 beetles / tree in 2010 and 2011, respectively) was in summer. Spring recorded the respective numbers 0.51 and 0.70 beetle / tree. Autumn showed the respective least beetle activity ( 0.15 and 0.18 beetle / tree). Beetles activity was stopped during winter. Moreover, the total numbers of beetles emerged during the whole year were 1.82 and 2.24 beetles / tree in 2010 and 2011, respectively. The respective means per tree / month were 0.15 and 0.19 beetles / tree / month.

Smoothed data in Table (1) and Figure (1) emphasized that $C$. varius had two brood of beetles' activity. The first one prevailed from the $2^{\text {nd }}$ half of March to the $2^{\text {nd }}$ half of July or $1^{\text {st }}$ half of August, while the second one was from the $2^{\text {nd }}$ half of June or July to $2^{\text {nd }}$ half of November in both years of study, 2010 and 2011. The three peaks of the broods were estimated during the $2^{\text {nd }}$ half of May or $1^{\text {st }}$ half of June, the $2^{\text {nd }}$ half of June or $1^{\text {st }}$ half of July and the $2^{\text {nd }}$ half of August or $1^{\text {st }}$ half of September, respectively.

\subsection{Progress of infestation:}

The cumulative numbers (seasonal cycle) of emerged beetles (Table, 1 and Figure, 1) was 7-7.5 months of beetles activity followed by 4.5-5.0 months of beetles inactivity. Infestation was almost doubled during only one year (from 1.82 beetles in 2010 to 4.06 beetles in 2011 / tree / year), thus, need urgent control of the pest year after another. 


\subsection{Effect of temperature and relative humidity on beetles activity:}

Statistical analysis in Table (2) revealed that the fluctuation in beetles population was highly significant and positively correlated with the DMxT (" $r$ " from 0.7959 to 0.8417 ) and DMT ("r" from 0.7472 to 0.7726 ), but the DMnT ("r": from 0.6673 to 0.6841 ) in both 2010 and 2011. On the other hand, the effect of DMRH much varied on the fluctuation in the beetles' population showing insignificant and positively correlation (" $r$ ": 0.2418 ) in 2010 , but insignificant and negatively correlation ("r": - 0.0492) in 2011.

Table 1 . Mean number of $C$. varius beetles in mango orchards at Ismilia governorate during 2010 and 2011 seasons.

\begin{tabular}{|c|c|c|c|c|c|c|c|}
\hline \multirow{3}{*}{\multicolumn{2}{|c|}{$\begin{array}{c}\text { Date of } \\
\text { inspection }\end{array}$}} & \multicolumn{6}{|c|}{ Mean no. of beetles $\backslash$ tree } \\
\hline & & \multicolumn{3}{|c|}{2010 season } & \multicolumn{3}{|c|}{2011 season } \\
\hline & & Actual & Smoothed & Cumulative & Actual & Smoothed & Cumulative \\
\hline \multirow[t]{2}{*}{ Jan. } & $1-15$ & 0.00 & 0.00 & 0.00 & 0.00 & 0.00 & 1.82 \\
\hline & $16-31$ & 0.00 & 0.00 & 0.00 & 0.00 & 0.00 & 1.82 \\
\hline \multirow[t]{2}{*}{ Feb. } & $1-15$ & 0.00 & 0.00 & 0.00 & 0.00 & 0.00 & 1.82 \\
\hline & $16-29$ & 0.00 & 0.00 & 0.00 & 0.00 & 0.00 & 1.82 \\
\hline \multirow[t]{2}{*}{ Mar } & $1-15$ & 0.00 & 0.00 & 0.00 & 0.00 & 0.00 & 1.82 \\
\hline & $16-31$ & 0.00 & 0.00 & 0.00 & 0.00 & 0.00 & 1.82 \\
\hline \multicolumn{2}{|c|}{ Winter } & 0.00 & & & 0.00 & & \\
\hline \multirow[t]{2}{*}{ Apr. } & $1-15$ & 0.00 & 0.00 & 0.00 & 0.01 & 0.01 & 1.83 \\
\hline & $16-30$ & 0.02 & 0.02 & 0.02 & 0.03 & 0.04 & 1.86 \\
\hline \multirow[t]{2}{*}{ May } & $1-15$ & 0.04 & 0.05 & 0.06 & 0.07 & 0.09 & 1.93 \\
\hline & $16-31$ & 0.11 & 0.11 & 0.17 & 0.18 & 0.14 & 2.11 \\
\hline \multirow[t]{2}{*}{ Jun. } & $1-15$ & 0.19 & 0.16 & 0.36 & 0.12 & 0.18 & 2.23 \\
\hline & $16-31$ & 0.15 & 0.18 & 0.51 & 0.29 & 0.23 & 2.52 \\
\hline \multicolumn{2}{|c|}{ Spring } & 0.51 & & & 0.70 & & \\
\hline \multirow[t]{2}{*}{ Jul. } & $1-15$ & 0.24 & 0.20 & 0.75 & 0.20 & 0.20 & 2.72 \\
\hline & $16-31$ & 0.17 & 0.20 & 0.92 & 0.10 & 0.16 & 2.82 \\
\hline \multirow[t]{2}{*}{ Aug. } & $1-15$ & 0.21 & 0.23 & 1.13 & 0.22 & 0.19 & 3.04 \\
\hline & $16-31$ & 0.32 & 0.26 & 1.45 & 0.23 & 0.26 & 3.27 \\
\hline \multirow[t]{2}{*}{ Sep. } & $1-15$ & 0.20 & 0.21 & 1.65 & 0.36 & 0.30 & 3.63 \\
\hline & $16-30$ & 0.12 & 0.13 & 1.67 & 0.25 & 0.25 & 3.88 \\
\hline \multicolumn{2}{|c|}{ Summer } & 1.16 & & & 1.36 & & \\
\hline \multirow[t]{2}{*}{ Oct. } & $1-15$ & 0.09 & 0.09 & 1.76 & 0.12 & 0.13 & 4.00 \\
\hline & $16-31$ & 0.05 & 0.03 & 1.81 & 0.04 & 0.05 & 4.04 \\
\hline \multirow[t]{2}{*}{ Nov. } & $1-15$ & 0.01 & 0.02 & 1.82 & 0.02 & 0.02 & 4.06 \\
\hline & $16-30$ & 0.00 & 0.00 & 1.82 & 0.00 & 0.005 & 4.06 \\
\hline \multirow[t]{2}{*}{ Dec. } & $1-15$ & 0.00 & 0.00 & 1.82 & 0.00 & 0.00 & 4.06 \\
\hline & $16-31$ & 0.00 & 0.00 & 1.82 & 0.00 & 0.00 & 4.06 \\
\hline \multicolumn{2}{|c|}{ Autumn } & 0.15 & & & 0.18 & & \\
\hline \multicolumn{2}{|c|}{ Grand Total } & 1.82 & & 1.82 & 2.24 & & 4.06 \\
\hline \multicolumn{2}{|c|}{ Mean/tree/ Month } & 0.15 & & & 0.19 & & \\
\hline
\end{tabular}




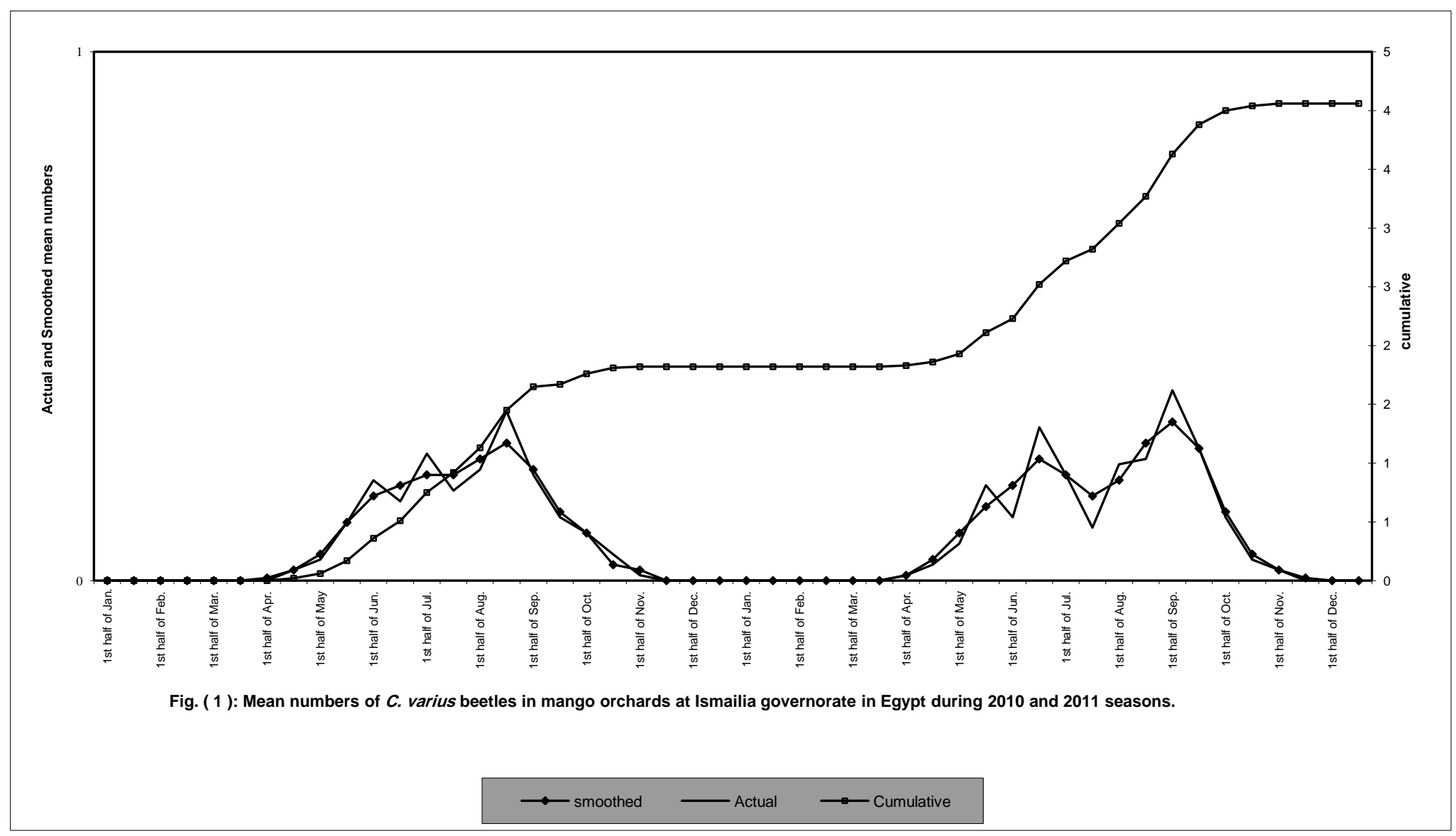


Table 2. Commencement, peak, last dates, and broods of $C$. varius beetles in mango orchards at Ismailia governorate, during 2010 and 2011 seasons.

\begin{tabular}{|c|c|c|}
\hline \multirow[t]{2}{*}{ Statement } & \multicolumn{2}{|c|}{ Year } \\
\hline & 2010 & 2011 \\
\hline Flight Commencement & $2^{\text {nd }}$ half of April & 1st half of April \\
\hline Peaks: $1^{\text {st }}$ peak & $1^{\text {st }}$ half of June & $2^{\text {nd }}$ half of May \\
\hline $2^{\text {nd }}$ peak & $1^{\text {st }}$ half of July & $2^{\text {nd }}$ half of June \\
\hline $3^{\text {rd }}$ peak & $2^{\text {nd }}$ half of August & $1^{\text {st }}$ half of September \\
\hline Last flight & $1^{\text {st }}$ half of November & $1^{\text {st }}$ half of October \\
\hline Broods: $1^{\text {st }}$ brood & $\begin{array}{c}2^{\text {nd }} \text { half of March to } \\
1^{\text {st }} \text { half of August }\end{array}$ & $\begin{array}{c}2^{\text {nd }} \text { half of March to } \\
2^{\text {nd }} \text { half of July }\end{array}$ \\
\hline $2^{\text {nd }}$ brood & $\begin{array}{l}2^{\text {nd }} \text { half of June to } \\
2^{\text {nd }} \text { half of November }\end{array}$ & $\begin{array}{c}1^{\text {st }} \text { half of July to } \\
2^{\text {nd }} \text { half of November }\end{array}$ \\
\hline Simple correlation " $r$ " coefficients & & \\
\hline DMxT & 0.8417 & 0.7959 \\
\hline DMT & 0.7726 & 0.7472 \\
\hline $\mathrm{DMnT}$ & 0.6673 & 0.6841 \\
\hline DMRH & 0.2418 & -0.0492 \\
\hline Simple regression " $b$ " coefficients & & \\
\hline $\mathrm{DMxT}$ & 21.582 & 19.837 \\
\hline DMT & 20.585 & 20.489 \\
\hline $\mathrm{DMnT}$ & 19.849 & 18.270 \\
\hline DMRH & 0.058 & -4.714 \\
\hline
\end{tabular}

**: Significant at 0.01 levels (Highly significant)

*: Significant at 0.05 levels (Significant)

\section{Discussion and conclusion:}

Monitoring studies (especially the sesonal fluctuation of insect pest population, progress of infestation, seasonal cycle, and effect of the main weather factors on the target pests) are essential in planning successful and effective "Integrated Control Programs" for the management of boring insect pests (El-Sherif and Tadros, 1985).

Survey studies (Hashim, 2009) indicated that dominant and economically important boring insect pests in mango orchards are the Coleopterous species: Chlorophorus varius, Macrotoma palmate, Pseudocastalia aegyptiaca, Batocera rufomaculata, Stromatium vulvum Villers., Ptosima undecimmaculata, Belionota 
scutellaris, Chrysobothris dorsata, Anthaxia angustipennis, Niphona picticornis, Scolytus amygdale, Xylotrechus antilope, Hypothenemus eruditus, Xyleborus similis, Xyleborinus saxeseni, Mesites cunipes, Rhyncolus cylindricus, Lyctus africanus, Gastrallus striatus, Tropiderinus munieri, Bostrychopsis reichei, Dinoderus bifoveolatus, D. minutus, Enneadesmus obtusedentatus, E. trispinosa, E. forficula, Phonapate frontalis, Sinoxylon sudanicum.

Literature is lacking concerning such studies on Chlorophorus varius abroad. However, in Egypt, there were some researches in this respect. The previous results are somewhat in agreement with Kinawy et al. (1993) on figs, Tadros (1994) on peaches, and Tadros et al. (2006) on apricots who monitored the seasonal fluctuation of $C$. varius population in fruit orchards in Egypt, and stated that emergence started almost around May / June and continued until October / November and the temperature (but not R. H.) influenced the development of $C$. varius.

\section{REFERENCES}

1. Abdel-Hamid, E.A. 2005. Ecological studies on some fruit tree borers in certain stone fruit orchards and their control. Ph.D. Thesis, Fac. of Science Cairo Univ.

2. El-Sherif, S.I. and A.W. Tadros. 1985. Screening of certain insecticides for the control of the wasp beetle, Chlorophorus varius Mull. (Coleoptera: Cerambycidae) on grapevine. Bull. Fac. Agric., Univ. of Cairo, Egypt, 36 (1): 601-608.

3. Hashim, S. M. 2009. Ecological and Control Studies on Mango Tree Borers and Their Natural Enemies in Egypt. Ph D Thesis, Faculty of Science, Cairo University.

4. Kinawy, M.M., F.F. Abd-Allah and A.W. Tadros. 1993. Emergence of adults of Chlorophorus varius and its relation to climatic conditions in fig orchards. Communications in Science \& Development Res., Alexandria, Egypt. 42 (644): 55-65.

5. Snedecor, W and A. Cochran. 1990. Statistical Methods. The Iowa State Univ. press, Ames, Iowa, USA.

6. Tadros, A.W. 1994. Monitoring the population of the wasp beetle, Chlorophorus varius Mull. (Coleoptera: Cerambycidae) on peach and its hosts in Egypt. Egypt. J. Agric. Res., 72 (1): 103-115. \{ $5^{\text {th }}$ Professional Fruit Workers Conf., Ashville, North Carolina, USA, Oct. 17-18, 1990, 5 (16)\}.

7. Tadros, A.W., A. M. Abdel-Rahman and E. A. Abdel-Hamid. 2006. Stone Fruit Pests: (5) Monitoring the major apricot tree borers (Ptosima undecimmaculata, Chlorophorus varius, Macrotoma palmata and Scolytus amygdall) in Egypt. Egypt. J. Agric. Res., Egypt, 84 (6): 1789-1809. 


\section{تتبع تعداد حفار ساق الخوخ ذو القرون الطويلة.Chlorophorus varius Mull في حدائق المانجو في مصر}

\section{صلاح محروس هاثم}

معهُ بحوث وقاية النباتات- مركز البحوث الزراعية- وزارة الزراعة- الدقي - الجبزة- مصر.

يعتبر حفار ساق الخوخ ذو القرون الطويلة C. varius من أهم حفارات أشجار الفاكهة

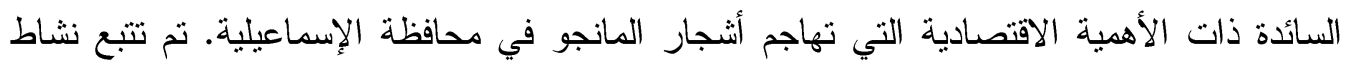

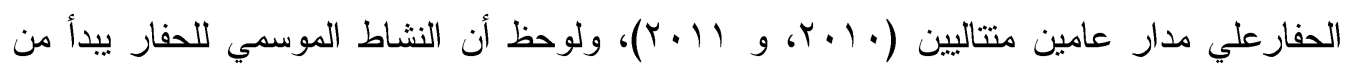

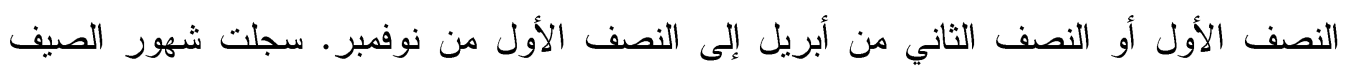

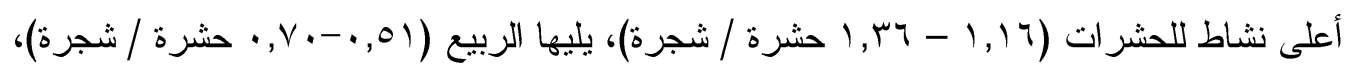
ثم الخريف (10,•-11, 1, حشرة / شجرة)، في حين توقف النشاط خلال الثتاء. بلغ إجمالي عداد

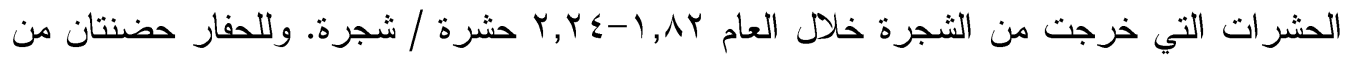
النشاط خلال العام. و هناك دورة من نشاط الحشرات لمدة V - V,O شهر • وقد تضاعفت الإصابة

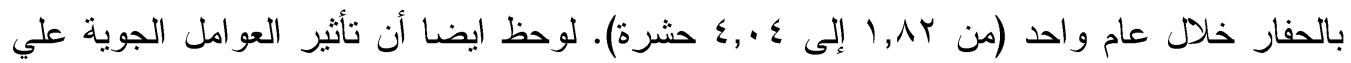
نشاط الحفارات موجب ومعنوي في معظم الأحوال مع درجات الحرارة الصغري والمتوسطة و العظمي، ولكنها سالبة أو موجبة وغير معنوية مع منوسط الرطوبة النسبية ، و في جميع الأحوال تضاعفت الإصابة بالحفار خلال عام واحد مما يستوجب المكافحة المستدامة. 